\title{
WIGGLE-MATCH DATING OF TREE-RING SEQUENCES FROM THE EARLY IRON AGE DEFENSIVE SETTLEMENT MOTRONINSKOE GORODISHCHE IN MIELNIKI (CENTRAL UKRAINE)
}

\author{
Jan Chochorowski ${ }^{1}$ Marek Krąpiec ${ }^{2}$ - Sergej Skoryj ${ }^{3}$ - Vadim Skrypkin ${ }^{4}$ \\ ABSTRACT. In 2002-2003, excavations were carried out within the early Iron Age fortified settlement of Motroninskoe \\ Gorodishche in Mielniki (central Ukraine, obl. Cherkassy). The excavations revealed relics of a charred wooden structure \\ in the core of the earth rampart, originally forming the outside fortification line of the settlement. Dendrochronological \\ analysis of 20 charred pieces of the oakwood from the rampart demonstrated that they all represented a single construction \\ phase. However, the chronology produced from them spanned only $62 \mathrm{yr}$, and the attempts of dating against the European \\ oak standards were unsuccessful. For absolute dating, radiocarbon analysis was conducted on nine samples consisting of \\ 4-8 tree rings, relatively dated and coming from selected timbers, of which dendrochronological sequences defined the \\ above chronology. The wiggle-matching method allowed to determine the two most plausible periods tree cutting: 665-630 \\ or $625-520 \mathrm{BC}$. The construction date of the rampart outlines the beginning of construction of the fortification system of one \\ of the most heavily reinforced strongholds in eastern Europe raised by the local, settled population for defense against the \\ nomadic Scythians invading from the steppe. Taking into account historic data and other dated artifacts, it may be assumed \\ that the first period, 665-630 BC, would be more probable. This conclusion supports the historical process (crucial for eastern \\ Europe) of migration of the Iranian Scythians from inside Asia and settling in areas around the Black Sea.
}

\section{INTRODUCTION}

The archaeological investigations on a complex of sites at Mielniki ( $230 \mathrm{~km}$ SE from Kiev, near the mouth of the Tyasmin River into the Dnieper), conducted in 2002-2003 and directed by J Chochorowski and S Skoryj, present a part of broader studies on history and culture of early historic nomads (the Scythians in particular) and their impact on the settled societies from the margins of the east European steppe zone in the 7th and 6th centuries BC. The investigated complex consists of a large fortified settlement ("Motroninskoe Gorodishche"; Bessonova and Skoryj 2001), more than 200 ha in area, and a nearby kurgan cemetery of approximately 80 barrows (Skoryj and Khokhorovski 2009). Along with excavating the inside of the settlement, excavations of the fortifications, in the form of two rings of ramparts, were also undertaken. The goal of the excavations was to investigate the stratigraphy of the fortification relics and to gather data for determination of their construction and chronology.

\section{ARCHAEOLOGICAL INVESTIGATIONS}

During two excavation seasons, the outer rampart was intersected with two trenches: one in the western part and the other one in the northwestern part of the settlement (Figure 1). In the western section, the rampart was $5 \mathrm{~m}$ high and $23.6 \mathrm{~m}$ wide at the base; the moat was $6.5 \mathrm{~m}$ deep and $15.8 \mathrm{~m}$ wide (Chochorowski and Skoryj 2006). The complex stratigraphic sequence allowed to distinguish three successive building phases (Figure 2). The architecture of the fortifications was most complex in the first, initial phase of their existence. At that time, the basic element of the rampart was a wooden structure built of massive beams, usually $\sim 20 \mathrm{~cm}$ in diameter. The structure consisted of a stockade, with poles placed $15-20 \mathrm{~cm}$ from each other. From the inside, the stockade was supported

1. Institute of Archaeology, Jagiellonian University, ul. Gołębia 11, 31-007 Kraków, Poland.

2. Faculty of Geology, Geophysics and Environmental Protection, AGH - University of Science and Technology, Al. Mickiewicza 30, 30-059 Kraków, Poland. Corresponding author. Email: mkrapiec@agh.edu.pl.

3. Institute of Archaeology National Academy of Sciences of Ukraine, Heroyiv Stalingrada Ave. 12, 04210 Kiev, Ukraine.

4. Institute of Environmental Geochemistry National Academy of Sciences of Ukraine, Palladin Ave. 34 a, 03680 Kiev, Ukraine.

Proceedings of the Radiocarbon and Archaeology 7th International Symposium Ghent, Belgium, April 2013 | Edited by Mark Van Strydonck, Philippe Crombé, and Guy De Mulder (C) 2014 by the Arizona Board of Regents on behalf of the University of Arizona 


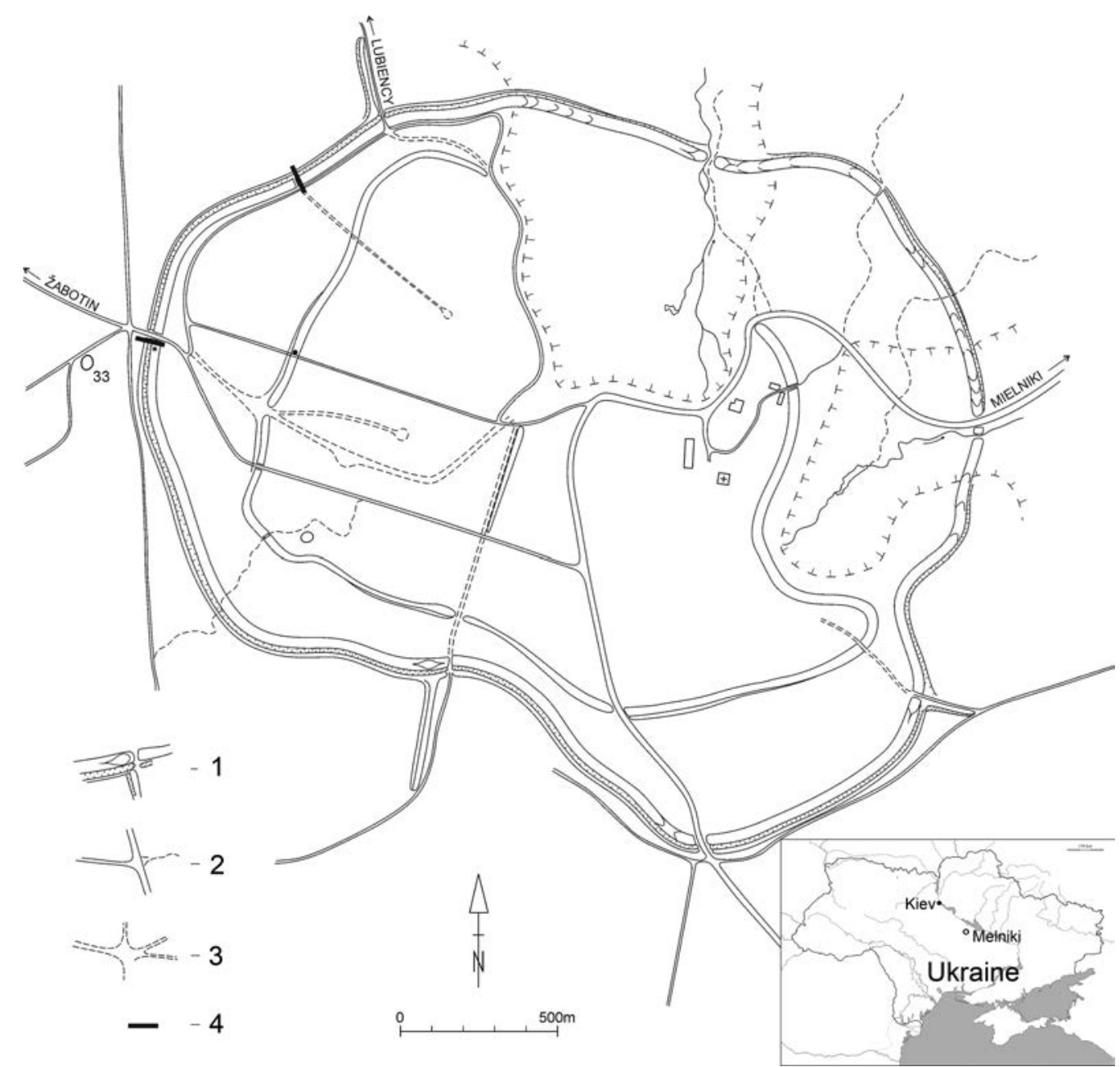

Figure 1 Plan of Motroninske Gorodishche: 1 - ramparts; 2 - contemporary roads; 3 - old roads detectable on aerial photographs; 4 - archaeological trenches.

by a kind of a barrier made from horizontally arranged beams. The barrier was $2 \mathrm{~m}$ wide at its base, and reached $1 \mathrm{~m}$ in height (Figure 3). Its surface was reinforced with transverse beams. The whole structure most likely played the role of a foundation for a gate, originally located in the site of the recent road. The whole wooden structure was covered with earth, which stabilized it and protected it from fire. In the first phase, the earth rampart was $\sim 14 \mathrm{~m}$ wide at the base and $\sim 2.8 \mathrm{~m}$ high. After a violent destruction (by fire) of that oldest defensive structure, it was quickly rebuilt, in even more monumental form. After another destruction (by fire as well), however, the outer fortifications ceased to be used. It was only after some time that they were rebuilt, but in a different form. The chronology of the reconstruction and functioning of the fortifications during the third building phase could be established on the basis of abundant ceramic material discovered in the moat, which was cleared and deepened in particular subphases. This material indicates that the third, youngest phase should be dated to the second half of the 6th to the beginning of the 5th centuries BC. In this context, finds of imported Greek pottery are of particular importance, especially parts of amphorae, among which fragments of Proto-Thassos and Thassos amphorae dated to the first half of the 5th century $\mathrm{BC}$. They mark the upper limit for the functioning of the outer ring of the fortifications. 


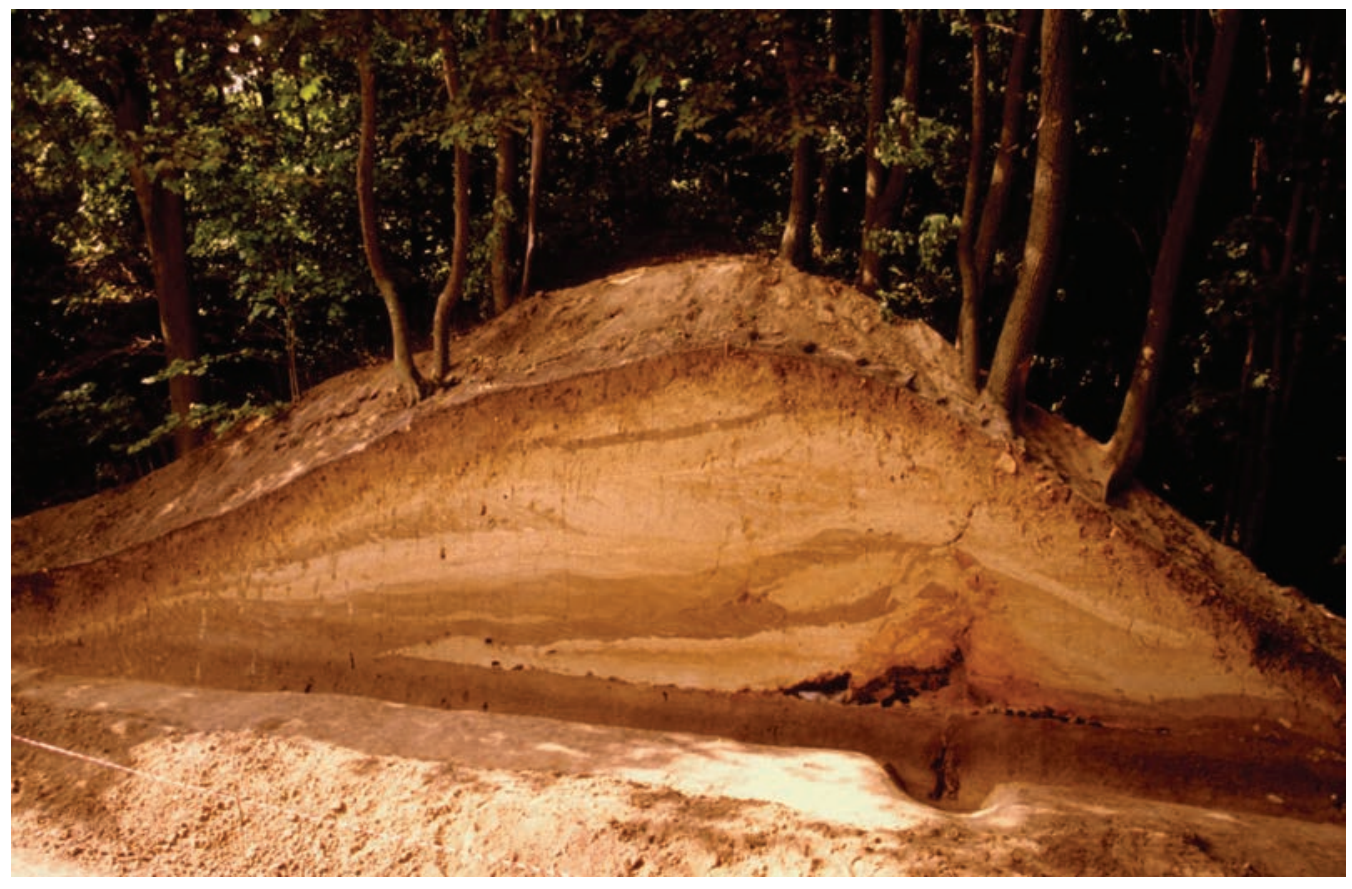

Figure 2 Cross-section of the rampart in the western part of Motroninske Gorodishche (by the road to Zhabotin)

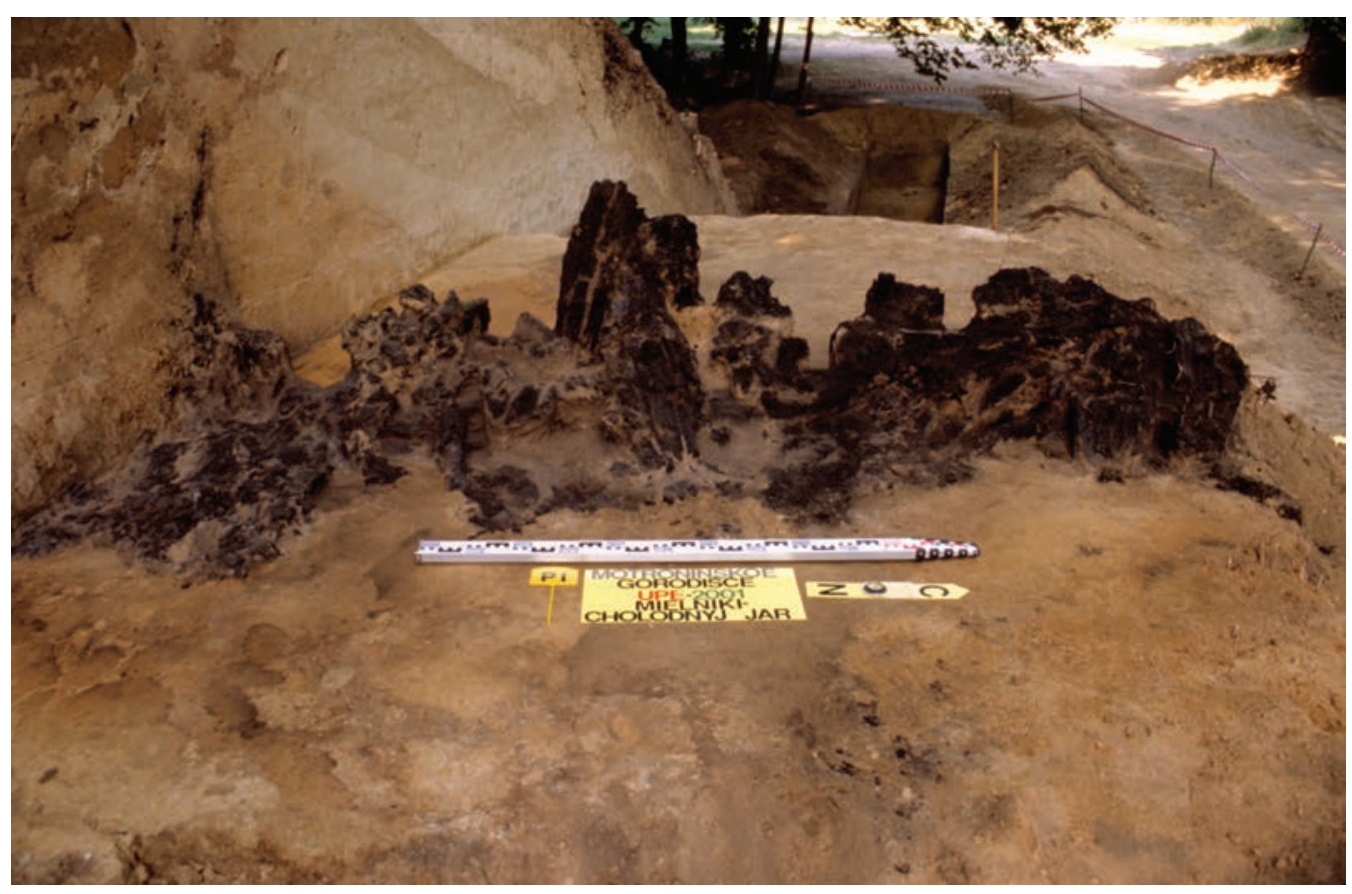

Figure 3 Upper parts of stockade poles and relics of the charred "barrier"; view from inside of the settlement 
The trench in the northwestern part of the settlement also cut through the rampart and the deep moat behind it. This resulted in recording a complete stratigraphy of the deposits also in this part of the site, including the rampart, the moat, and its surroundings. The original height of the fortifications was $3 \mathrm{~m}$ in the first phase and $\sim 4.5 \mathrm{~m}$ in the second phase. In the third phase, the rampart should have been considerably higher, but its exact height is difficult to estimate. The cross-section through the moat revealed at least 11 or 12 successive stages of cleaning, deepening, or changing its position (Figure 4). The maximal depth of the moat calculated from the contemporary ground surface amounts to $3.9 \mathrm{~m}$ and its width to $10.3 \mathrm{~m}$.

Clear symptoms of decreasing care for the quality of the defensive structures seem to suggest that their degradation was to a large degree a natural process, reflecting lack of need for maintaining the defensive function of the settlement. Most likely, at the turn of the 6th and 5th centuries BC, or in the early 5 th century BC, certain sociopolitical factors, which previously stimulated that need, disappeared.

\section{MATERIAL AND METHODS}

Analyses were conducted on charred wood sampled from the best preserved barricade, built of beams, which formed a side element (kind of anchoring) of the gate structure leading to the settlement from the west. The location of the research trench with the structure sampled is presented in Figure 1. As the charred wood exhibited a relatively legible structure of the tree rings, it was suitable for dendrochronological analysis. Almost all elements of the exposed structure were made from the oakwood. Requirements of the dendrochronological method (i.e. minimal number of tree rings higher than 25 , legible anatomical structure of wood, undisturbed rings) were fulfilled by 20 samples of the charred oakwood. Unfortunately, they were mostly fragments of trunks and boughs of relatively young trees, containing from a dozen or so to several tens of annual growth rings.

Measurements of the annual growth width, with $0.01 \mathrm{~mm}$ accuracy, were made using the DENDROLAB 1.0 apparatus in the Dendrochronological Laboratory of the AGH - University of Science and Technology in Kraków (Poland). The measurements were registered and the annual growth

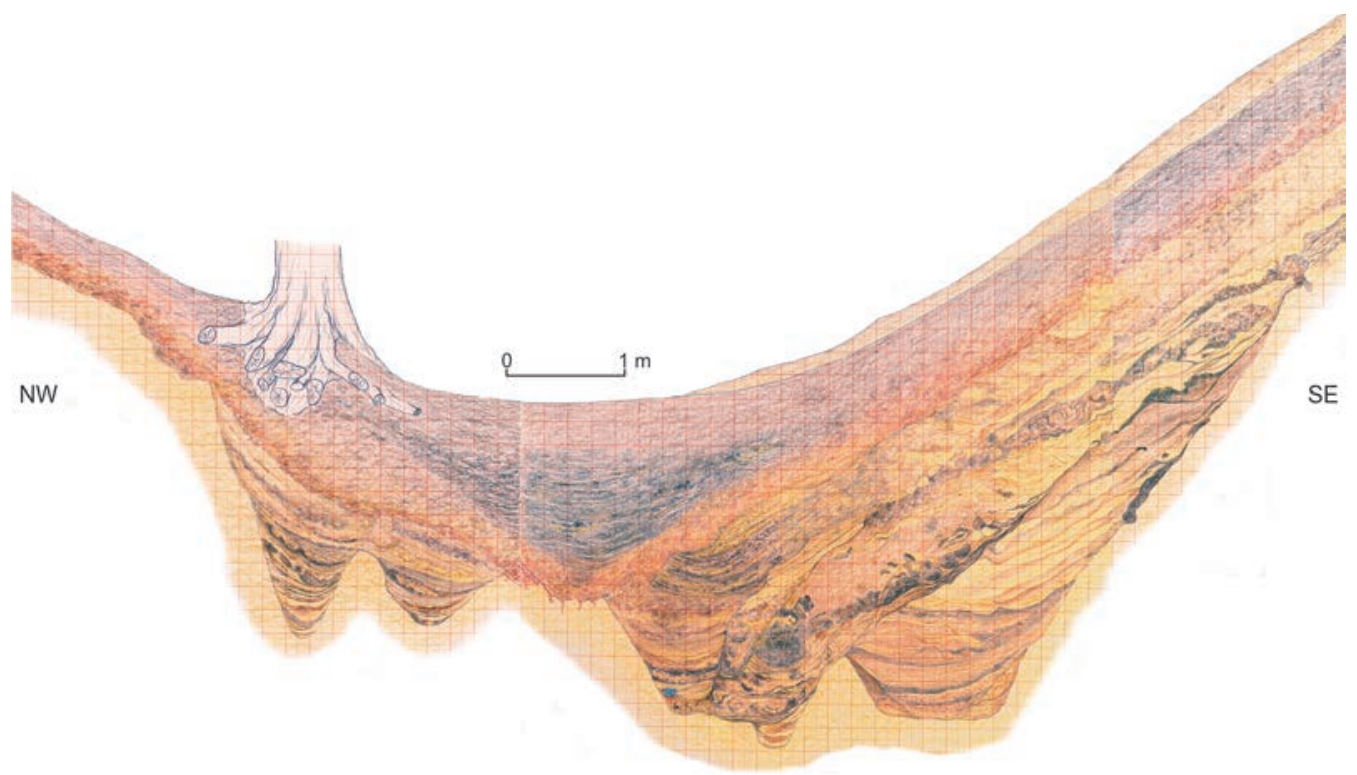

Figure 4 Stratigraphy of the moat in successive stages of its functioning (the trench in the northern part of the site) 
sequences were graphically presented using the package of programs TREE-RINGS (Krawczyk and Krapiec 1995). Correlation and determination of the best fitting positions of the individual sequences were made with the programs TSAP (Rinn 2005) and COFECHA (Holmes 1999). Contemporaneous sequences were identified on the basis of high values of Pearson's linear correlation coefficient $r$ and $t$ value (Baillie and Pilcher 1973), as well as visual comparison of dendrograms.

Radiocarbon dating, by the liquid scintillation counting (LSC) technique, was carried out in the Laboratory of the Institute of Environmental Geochemistry, National Academy of Sciences of Ukraine in Kiev (Ukraine). Determination of the age with the ${ }^{14} \mathrm{C}$ method was made on sequences appropriately chosen of annual growth of nine samples of wood, comparatively dated dendrochronologically. In the laboratory, the wood was chemically pretreated with the acid-alkali-acid (AAA) method. Standard synthesis of benzene was carried out on the carbonized wood samples (Skripkin and Kovalyukh 1994). ${ }^{14} \mathrm{C}$ concentration measurements were carried out by LSC of $\beta$ radiation. Measurements were made with the Quantulus ${ }^{\mathrm{TM}} 1220$ spectrometer. The ${ }^{14} \mathrm{C}$ ages of the charcoal samples were calculated using assumed values of $\delta^{13} \mathrm{C}$.

Since the age of wood relatively dated with the dendrochronological method had to be determined independently, the wiggle-matching method was applied. The wiggle-matching technique, together with its mathematical assumptions, is described well by Bronk Ramsey et al. (2001). In this work, wiggle-matching analysis was performed with the program OxCal v 4.2.2 (Bronk Ramsey 2009) and the calibration curve IntCal09 (Reimer et al. 2009). Nine samples from selected fragments of the tree-ring sequences were relatively dated dendrochronologically. The D_Sequence model of OxCal with defined gaps was employed to account for the final tree rings of the oak chronology. The gap was a precisely known interval between the center of the relatively dated tree-ring series submitted for ${ }^{14} \mathrm{C}$ dating. The best match between the calibration curve and tree-ring data was calculated using the agreement index A, which indicates the extent to which the posterior distribution overlaps with the individual ${ }^{14} \mathrm{C}$ distributions in a similar way to a $\chi^{2}$ test (Bronk Ramsey et al. 2001).

\section{RESULTS}

Anatomical analysis of the charred wood pieces from the rampart structure demonstrated that the predominating species was oak (Quercus sp.). Single samples of ash (Fraxinus excelsior) and elm (Ulmus sp.) were noted as well. Out of 20 samples of the oakwood complying with the requirements of the dendrochronological method, none retained the sapwood layer, which could allow for identification of the season in which the trees were cut down.

Dendrochronological measurements resulted in relatively short sequences, from 28 to 56 annual growth rings. Among the samples measured, timbers with about 40 growth rings prevailed, which may indicate intentional usage of relatively young trees, not more than $20-30 \mathrm{~cm}$ in diameter.

Computer correlations and visual comparisons of the dendrograms allowed to determine which tree species dated had grown at the same time. On the basis of the 12 most convergent dendrochronological sequences, the 62-yr chronology, labeled U_MIEAA, was constructed. It is presented, together with its components, in Figure 5. Values of the coefficients $t$ and $r$, reflecting similarity between the chronology and the individual component samples, are presented in Table 1. Results of relative dendrochronological dating of wood from the settlement ramparts are presented in the block diagram in Figure 6. Taking into account the fact that, as a result of fire only the heartwood part was preserved, whereas less-resistant sapwood left only traces, it may be inferred that the wood for constructing the ramparts was gathered within a short interval of only a few years. It is even highly probable that this could take place within a single year, and differences in dating the last 
heartwood growths result from degradation of not only sapwood, but some parts of the heartwood rings as well. In such a situation, only the earliest possible time of cutting the trees down could be determined. Therefore, an equivalent of the average number of sapwood rings should be added to the dating of the youngest preserved heartwood rings. In this part of Europe, it amounts to about 10 rings (see Zielski and Krąpiec 2004). Hence, the trees could have been felled $\sim 72$ relative yr prior.

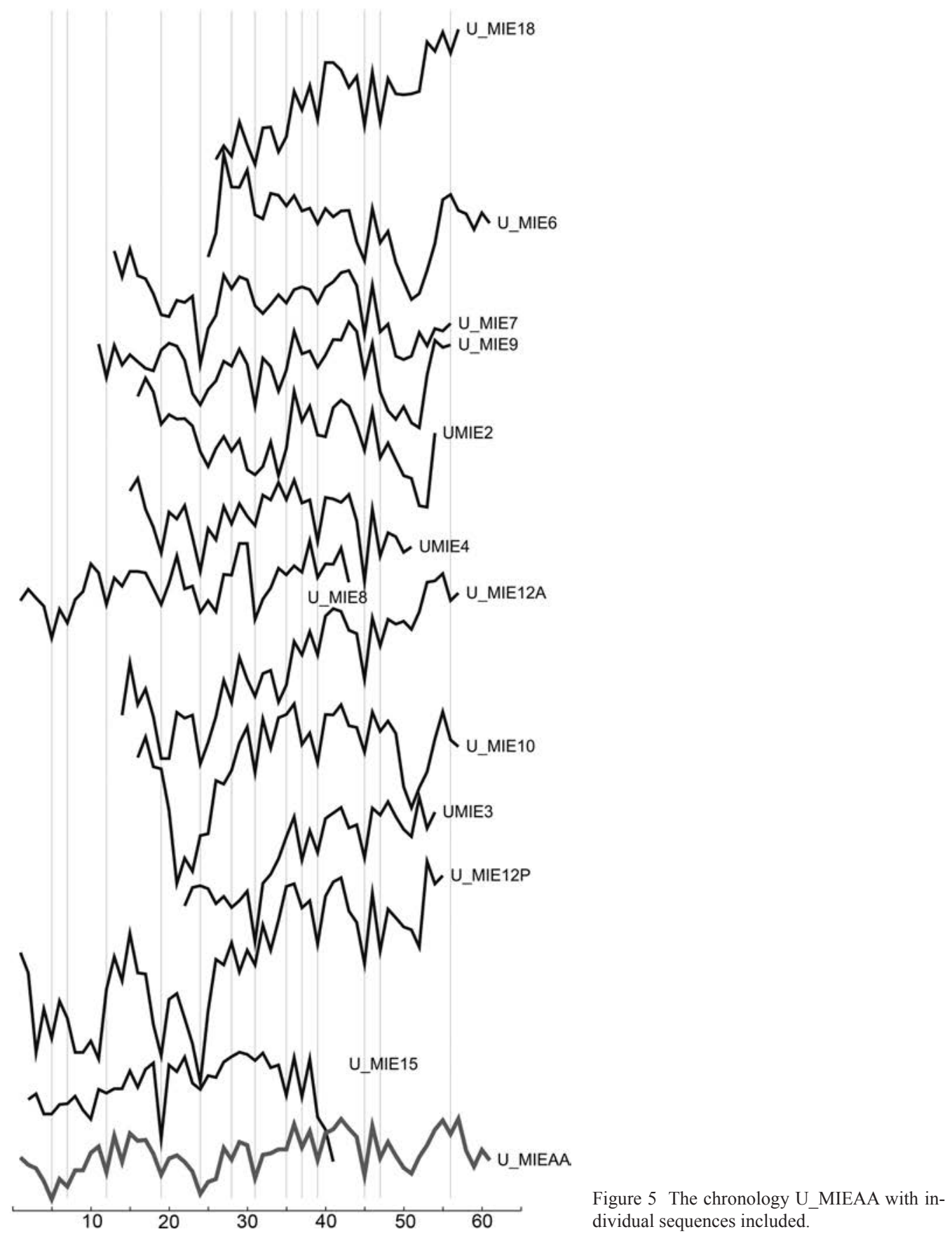


Table 1 Selected statistical parameters of the chronology U_MIEAA.

\begin{tabular}{lllll}
\hline Lab code & Nr of years & Sapwood & $\begin{array}{l}\text { Correlation with chrono- } \\
\text { logy_U_MIEAA }[t]\end{array}$ & $\begin{array}{l}\text { Correlation with chrono- } \\
\operatorname{logy} \text { U_MIEAA }[r]\end{array}$ \\
\hline U_MIE2 & 39 & - & 6.1 & 0.724 \\
U_MIE3 & 33 & - & 4.5 & 0.584 \\
U_MIE4 & 37 & - & 10.2 & 0.876 \\
U_MIE6 & 37 & - & 4.6 & 0.640 \\
U_MIE7 & 44 & - & 6.2 & 0.707 \\
U_MIE8 & 43 & - & 6.8 & 0.740 \\
U_MIE9 & 46 & - & 4.8 & 0.602 \\
U_MIE10 & 42 & - & 4.3 & 0.554 \\
U_MIE12A & 44 & - & 8.2 & 0.799 \\
U_MIE12P & 56 & - & 4.7 & 0.544 \\
U_MIE15 & 40 & - & 5.2 & 0.645 \\
U_MIE18 & 32 & - & 7.1 & 0.810 \\
\hline
\end{tabular}

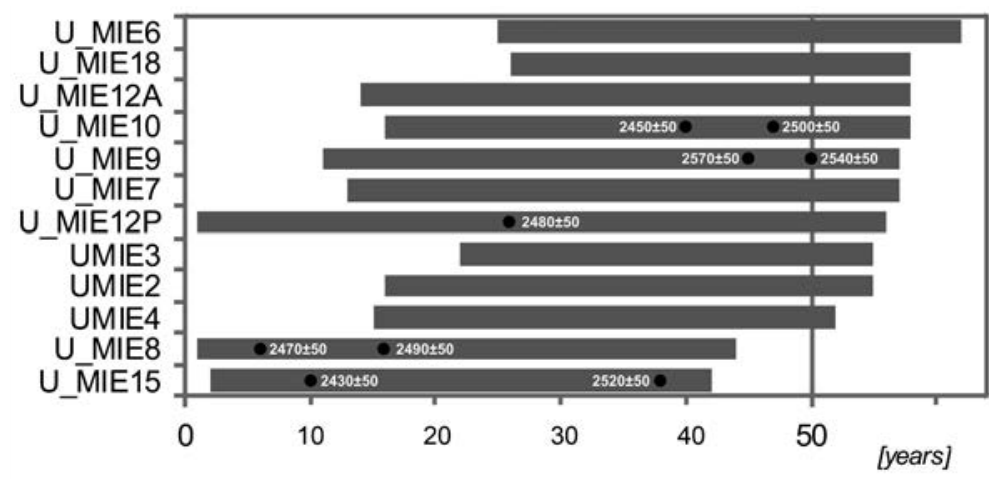

Figure 6 Correlation block diagram of dendrochronological sequences forming the chronology U_MIEAA (selected tree rings used in the wiggle-matching marked with dots).

The chronology produced was compared with available oak chronologies from Poland and neighboring countries (Krąpiec 2001; Zielski and Krąpiec 2004). Unfortunately, no synchronous position, allowing for unequivocal dating, could be found. The main cause of this failure is in the low number of annual growth rings in the chronology.

The time period represented by the samples from the rampart was determined with the wiggle-matching method, commonly used for dating floating dendrochronological patterns (Kruse et al. 1980; Pearson 1986; Krąpiec 1992). It was also applied in studies on the Scythian posts from Asia (Vasiliev et al. 2001).

From the timbers of which dendrochronological sequences outline the U MIEAA chronology, nine samples, each consisting of 4-8 tree rings dated relatively, were selected for the ${ }^{14} \mathrm{C}$ LSC dating. The results for the tree rings selected for ${ }^{14} \mathrm{C}$ dating and their positions in the chronology are presented in Figure 6 and Table 2.

Results of the conventional age determination, together with corresponding uncertainty ranges, are presented in Table 2. For the Mielniki wiggle-matching, the agreement index for the complete D_Sequence was $100.5 \%$, with $\mathrm{An}=23 \%(n=9) .{ }^{14} \mathrm{C}$ results for the nine samples forming the U_MIEAA chronology, after the dependent calibration (Figures 7 and 8), indicate that the dates of 
Table 2 Sample description and conventional ages.

\begin{tabular}{llll}
\hline Sample description $^{\mathrm{a}}$ & Lab code $^{\mathrm{b}}$ & ${ }^{14}$ C age (BP) & Position in tree-ring chronology $^{\mathrm{c}}$ \\
\hline Mielniki, U_MIE8 & Ki-10319 & $2470 \pm 50$ & $2-9$ \\
Mielniki, U_MIE15 & Ki-10469 & $2430 \pm 50$ & $8-12$ \\
Mielniki, U_MIE8 & Ki-10320 & $2490 \pm 50$ & $14-18$ \\
Mielniki, U_MIE12 & Ki-10471 & $2480 \pm 50$ & $22-30$ \\
Mielniki, U_MIE15 & Ki-10472 & $2520 \pm 50$ & $31-39$ \\
Mielniki, U_MIE10 & Ki-10321 & $2450 \pm 50$ & $37-44$ \\
Mielniki, U_MIE9 & Ki-10323 & $2570 \pm 50$ & $43-47$ \\
Mielniki, U_MIE10 & Ki-10322 & $2500 \pm 50$ & $45-50$ \\
Mielniki, U_MIE9 & Ki-10324 & $2540 \pm 50$ & $48-51$ \\
\hline
\end{tabular}

${ }^{a}$ Site, sample name.

${ }^{b}$ Laboratory code of the Radiocarbon Laboratory of Institute of Environmental Geochemistry NAS of Ukraine, Kiev.

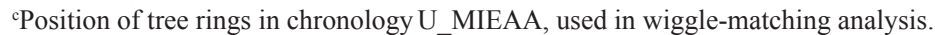

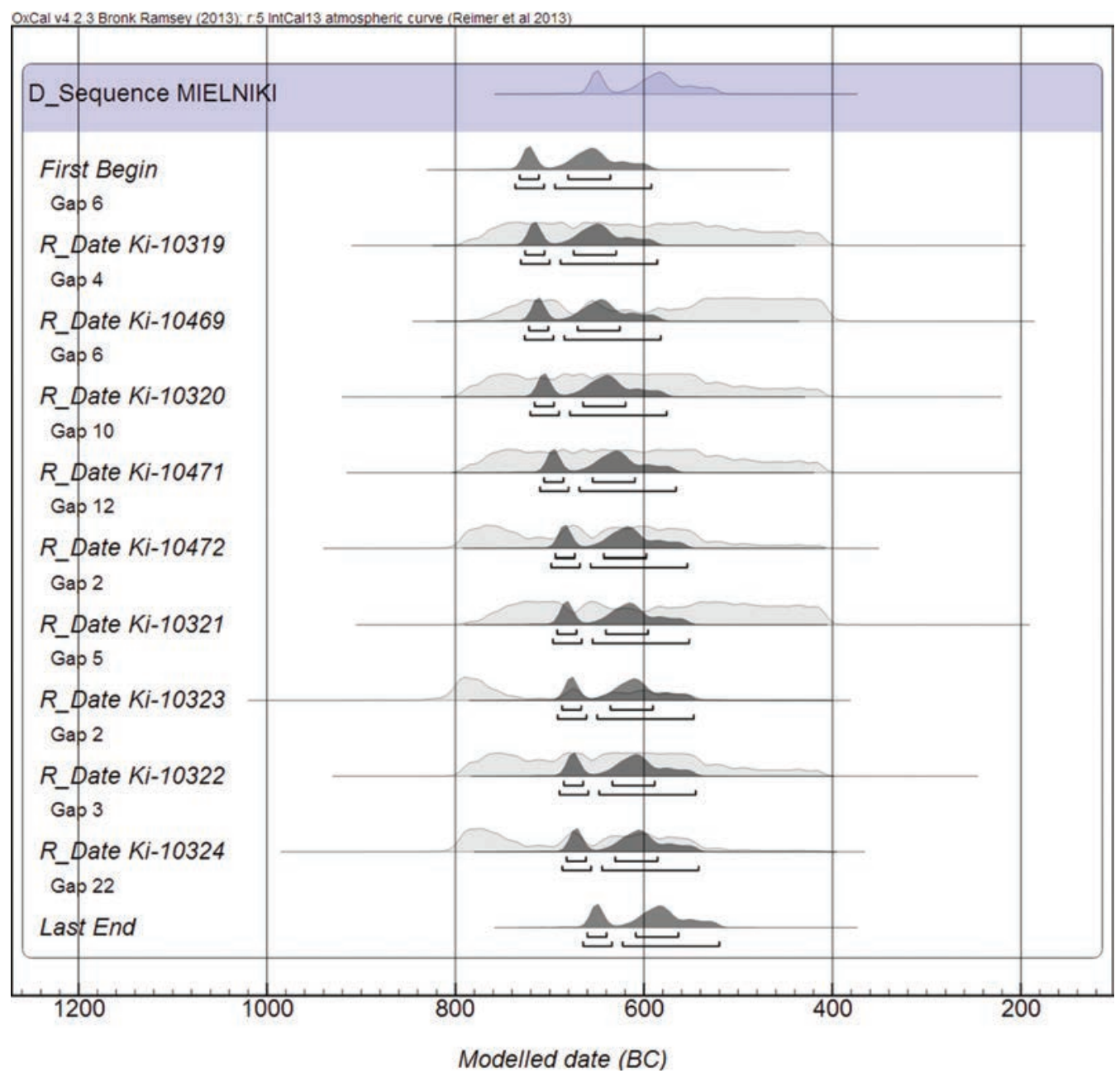

Figure 7 Wiggle-matching of the floating chronology U_MIEAA 


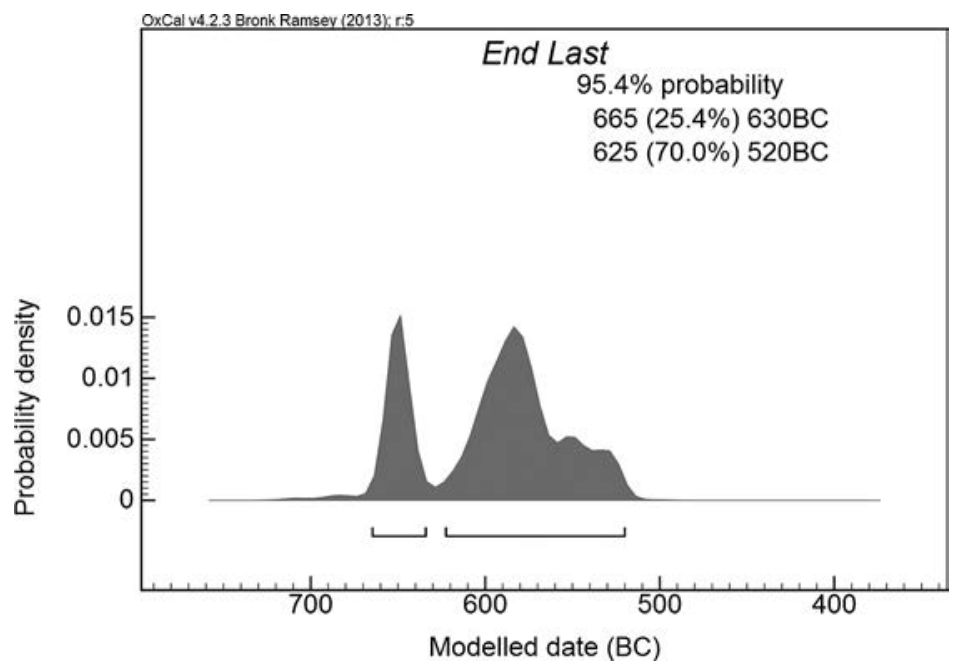

Figure 8 Calibrated position of cutting down the trees of the chronology U_MIEAA

cutting the oak trees down most probably fall in one of the periods: $665-630$ or $625-520 \mathrm{BC}$. The choice of the more plausible of these two periods was based on archaeological dating and analysis of the moat deposits. The fortified settlement was abandoned (according to indications of the archaeological dating) at the turn of the 6 th and 5 th centuries BC or at the beginning of the 5 th century BC. In that time, political and military power of the nomadic Scythians, after their defeat of the Persians (513 BC), reached its apogee, so further maintaining of defensive settlement structures by the settled population from forest and steppe areas of the Dnieper lost its raison d'être. Hence, the time of functioning of the fortified settlement could be quite accurately limited by its abandonment, dated archaeologically to the turn of the 6th and 5th centuries or beginning of the 5th century $\mathrm{BC}$, and the first phase of the rampart construction, dated with the wiggle-matching method. That period could be also approximately determined based on analysis of the laminated moat deposits. The laminated deposits consist of alternate bright and dark layers, presumably formed in annual cycles. The bright part formed in the summer period, when prevailing mineral material was delivered by the flow of rain waters, whereas the dark layer formed in the winter, when only the organic matter accumulated in the freezing conditions. As a result of filling with sediments, the moat lost its defensive advantages within a period of a dozen or so years. The excavations allowed to distinguish 11 or 12 cycles of filling the moat, which ended with deepening the moat and correction of its course. Hence, the time of functioning of the settlement could be estimated for a period of about $150 \mathrm{yr}$. This, in turn, could be a strong reason for supposing that the time of the first construction phase of the settlement ramparts fell in the first of the intervals determined with the wiggle-matching method, i.e. 665-630 BC.

\section{CONCLUSION}

Construction of the ramparts marked the beginning of construction of the fortification system of one of the most heavily reinforced strongholds in eastern Europe. It was raised by the local, settled population, for the defense against the nomadic Scythians invading from the steppe, most probably occurring in the period of 665-630 BC. Such a conclusion may be essential for analysis of the course of the historical process, crucial for eastern Europe, of migration of the Iranian Scythians from inside Asia and settling in the areas around the Black Sea. 


\section{ACKNOWLEDGMENTS}

The study was supported by the Institute of Archaeology, Jagiellonian University in Kraków and partly by the Faculty of Geology, Geophysics and Environmental Protection, AGH - University of Science and Technology in Kraków (project no 11.11.140.173).

\section{REFERENCES}

Baillie MGL, Pilcher JR. 1973. A simple crossdating program for tree-ring research. Tree-Ring Bulletin 33:7-14.

Bessonova SS, Skoryj SA. 2001. Motroninskoe gorodšče skifskoj èpochi (Motroninske Gorodishche-fortified settlement of the Scythian era). Kiev: Institute of Archaeology, The National Academy of Sciences of Ukraine; Kraków: Institute of Archaeology Jagellonian University. In Russian.

Bronk Ramsey C. 2009. Bayesian analysis of radiocarbon dates. Radiocarbon 51(1):337-60.

Bronk Ramsey C, van der Plicht J, Weninger B. 2001. 'Wiggle-matching' radiocarbon dates. Radiocarbon 43(2A):381-9.

Chochorowski J, Skoryj S. 2006. Mielniki, Raj. Čigirin, Obl. Čerkassy (Ukraine). Ein Burgwall und Kurgane der skythichen Zeit. Institute of Archaeology Jagiellonian University. Recherches archéologiques de 1999-2003:415-49.

Holmes RL. 1999. Users' Manual for Program COFECHA. Tucson: University of Arizona.

Krąpiec M. 1992. Skale dendrochronologiczne późnego holocenu południowej i centralnej Polski [Dendrochronological scales of the Late Holocene of southern and central Poland]. Kwartalnik AGH Geologia 18(3):37-119. In Polish.

Krąpiec M. 2001. Holocene dendrochronological standards for subfossil oaks from the area of southern Poland. Studia Quaternaria 18:47-63.

Krawczyk A, Krąpiec M. 1995. Dendrochronologiczna baza danych (Dendrochronological database). Materiały II Krajowej Konferencji: Komputerowe wspomaganie badan naukowych (Proceedings of the Second Polish Conference: Computers in Scientific Researches). Wrocław. p 247-52. In Polish.

Kruse HH, Linick TW, Suess HE, Becker B. 1980. Computer-matched radiocarbon dates of floating treering series. Radiocarbon 22(2):260-6.
Pearson GW. 1986. Precise calendrical dating of known growth-period samples using a 'curve fitting' technique. Radiocarbon 28(2A):292-9.

Reimer PJ, Baillie MGL, Bard E, Bayliss A, Beck JW, Blackwell PG, Bronk Ramsey C, Buck CE, Burr GS, Edwards RL, Friedrich M, Grootes PM, Guilderson TP, Hajdas I, Heaton TJ, Hogg AG, Hughen KA, Kaiser KF, Kromer B, McCormac FG, Manning SW, Reimer RW, Richards DA, Southon JR, Talamo S, Turney CSM, van der Plicht J, Weyhenmeyer CE. 2009. IntCal09 and Marine09 radiocarbon age calibration curves, 0-50,000 years cal BP. Radiocarbon 51(4):1111-50.

Rinn F. 2005. TSAP-Win. Time series analysis and presentation for dendrochronology and related applications. User Reference. Heidelberg.

Skoryj S, Khokhorovski J. 2009. Aristokraticheskij kurgan Skifskaja Mogila vblizi Motroninskogo gorodishcha (ukrainskaja Pravoberezhnaja Lesostep') [Aristocratic kurgan Skifskaya Mogila (Scythian grave) near Motroninskoe Fort (Ukrainian right bank Forest-Steppe Zone)]. Stratum Plus 3/20052009:234-76. In Russian.

Skripkin VV, Kovalyukh NN. 1994. An universal technology for oxidation of carbon-containing materials for radiocarbon dating. The Conference on Geochronology and Dendrochronology of Old Town's and Radiocarbon Dating of Archaeological Findings. Lithuania, Vilnius, 31 October-4 November 1994. Vilnius University Press. p 37-42.

Vasiliev SS, Bokovenko NA, Chugunov KA, Dergachev VA, Sementsov AA, Sljusarenko JU, Zaitseva GI. 2001. Tree-rings, "wiggle-matching" and statistics in the chronological studies of Scythian Age sites in Asia. Geochronometria 20:61-8.

Zielski A, Krąpiec M. 2004. Dendrochronologia. Warsaw: PWN. In Polish. 